\title{
Pelatihan Pembuatan Vermikompos di Desa Lokasi Baru Kecamatan Air Periukan Kabupaten Seluma
}

Agung Trisusilo, Indra Cahyadinata

Program Studi Agribisnis Fakultas Pertanian Universitas Bengkulu

\section{ARTICLE INFO}

RiwayatArtikel:

Draft diterima: 29 November 2021

Revisi diterima: 20 Desember 2021

Diterima: 22 Desember 2021

Tersedia Online: 27 Desember 2021

Corresponding author: atrisusilo@unib.ac.id

Citation: Trisusilo. A, dan Cahyadinata. I. 2021. Pelatihan Pembuatan

Vermikompos di Desa Lokasi Baru

Kecamatan Air Periukan Kabupaten

Seluma. ICOMES: Indonesian Journal of Community Empowerment and Service.

1(1), pp: 41-46

\begin{abstract}
ABSTRAK
Kegiatan ini bertujuan untuk meningkatkan kesadaran masyarakat Desa Lokasi Baru untuk membuat kotoran ternak menjadi pupuk kompos dengan metode vermikompos. Metode yang digunakan dalam kegiatan ini adalah kombinasi antara penyuluhan dan pelatihan terstruktur. Hasil dari kegiatan ini adalah peserta mampu melihat potensi sumberdaya yang mereka miliki berupa kotoran ternak dan mengolahnya menjadi pupuk vermikompos yang lebih bermanfaat dan bernilai ekonomi. Dalam pelaksanaannya peserta mengalami kendala pada tahap persiapan media perkembangan, penetasan telur cacing dan proses komposting. Meskipun dalam proses pelaksanaannya peserta menghadapi beberapa kendala, namun dengan pendampingan dari tim pengabdian mereka mampu menyelesaikan kendalakendala tersebut secara mandiri. Setelah mengikuti rangkaian kegiatan ini para peserta mengetahui bahwa limbah peternakan yang mereka hasilkan memiliki nilai ekonomi jika dikelola dengan baik. Oleh karena itu saat ini mereka telah mempraktikan ilmu yang didapat secara mandiri.
\end{abstract}

Kata kunci: kotoran ternak; Lumbricus sp.; vermikompos.

Keywords: shit livestock; Lumbricus sp.; vermicompost

\section{PENDAHULUAN}

Sektor pertanian Indonesia memiliki kontribusi yang besar terhadap pembangunan ekonomi bangsa. Menurut data pertumbuhan ekonomi pada triwulan III tahun 2020 yang dirilis oleh Badan Pusat Statistik (BPS), terlihat bahwa sektor pertanian tumbuh sebesar 2,5\%. Berdasarkan besaran Produk Domestik Bruto (PDB) bebagai sektor, hanya sektor pertanian yang mengalami pertumbuhan yang positif. Melihat data pada periode sebelumnya, yakni pada triwulan II tahun 2020, kontribusi sektor pertanian terhadap PDB juga mengalami peningkatan sebesar 2,19\% (Kementerian Pertanian RI, 2020).

Keberhasilan sektor pertanian tersebut tidak terlepas dari kontribusi masing-masing sub-sektor di dalamnya. Setiap sub-sektor yang terlibat memiliki besaran kontribusi yang berbeda. Hal ini tidak terlepas dari permasalahan yang dihadapi. Dalam pelaksanaannya masing-masing sub-sektor memiliki permasalahan yang dihadapi sehingga belum mampu mencapai target kontribusinya terhadap peningkatan PDB. 
Pada sub-sektor peternakan salah satu permasalahan yang dihadapi adalah belum tercapai target swasembada daging. Jumlah produksi daging sapi Indonesia sebanyak 490,42 ribu ton. Sedangkan jumlah konsumsi daging sapi dalam negeri mencapai 402,51 ribu ton. Meskipun secara jumlah terdapat surplus 87,91 ribu ton, namun pemerintah tetap melakukan impor sebanyak 73,5 ribu ton. Hal ini dikarenakan kualitas daging yang diproduksi dalam negeri belum mampu memenuhi quality control yang disyaratkan oleh industri pangan olahan, pariwisata dan perhotelan (Direktorat Jenderal Peternakan, 2019).

Produksi daging sapi sangat bergantung pada ketersediaan pakan berkualitas. Namun penyediaan pakan berkualitas terkendala dengan ketersediaan lahan guna produksi hijauan sebagai pakan ternak. Saat ini lahan pertanian di Indonesia mengalami penyusutan. Kondisi ini menjadi salah satu kendala dalam peningkatan produktivitas usaha peternakan sapi di Indonesia (Mulyani, dkk, 2016).

Sub sektor perkebunan juga mengalami kendala. Petani mengeluhkan harga pupuk an-organik yang semakin mahal. Hal ini menyebabkan keuntungan yang diperoleh petani menjadi lebih kecil. Masalah kedua yang muncul adalah peggunaan pupuk an-organik oleh petani menjadi masalah bagi kualitas tanah. Penggunaan pupuk jenis ini akan menyebabkan terjadinya pengikisan unsur hara dan berbagai mineral penting dalam tanah.

Desa Lokasi Baru adalah satu desa yang berada di Kecamatan Air Periukan Kabupaten Seluma. Desa ini berada sekitar $48 \mathrm{Km}$ dari Pusat Kota Bengkulu. Memiliki luas wilayah 543,09 hektar dengan alokasi pemanfaatan sebasar $80 \%$ berupa daratan lahan pertanian dan 14\% berupa lahan perumahan masyarakat (Anonim, 2017).

Berdasarkan hasil survai pendahuluan yang dilakukan pada hari Kamis, 1 Juli 2021 diketahui bahwa di lokasi baru terdapat 292 orang petani. Sebagian dari mereka membentuk 6 kelompok tani dan 1 gabungan kelompok tani (Gapoktan). Gapoktan ini bernama "Gapoktan Pendowo Bakti. Mereka yang tergabung dalam Gapoktan ini berprofesi sebagai petani sawit, karet, kelapa dan peternak. Pada sub sektor peternakan, desa ini memiliki potensi berupa 135 ekor sapi dan 72 ekor kambing. Dari ternak yang mereka miliki tersebut rata-rata perhari bisa didapatkan kotoran sapi sebanyak 2 ton dan $100 \mathrm{~kg}$ kotoran kambing.

Potensi yang mereka miliki berupa ternak ruminansia tersebut belum mampu dikelola dengan baik sehingga dapat mengoptimalkan produktivitas usahatani mereka. Selama ini kotoran ternak tersebut hanya dibuang ataupun teronggok begitu saja, Hal ini dikarenakan mereka tidak memiliki pengetahuan dan keterampilan dalam mengolah kotoran ternak hingga menjadi pupuk organik yang dapat digunakan dalam usahatani mereka. Jika potensi tersebut dapat dikelola dengan baik maka mereka dapat menghemat biaya penggunaan pupuk bagi usahatani mereka. Selain itu, limbah ternak yang dihasilkan tidak akan mencemari lingkungan. Oleh karena itu mereka berharap dapat diberikan pemahaman dan keterampilan tentang pembuatan pupuk organik seperti pupuk kompos dari kotoran ternak.

\section{METODE PELAKSANAAN}

Program pengabdian ini dimulai dengan proses penyamaan persepsi antara tim pengabdian dengan anggota kelompok tani beserta perangkat desa. Hal ini perlu dilakukan untuk memastikan keberlanjutan implementasi teknologi pasca program pengabdian yang direncanakan selesai. Dalam kegiatan ini tim pengabdian melakukan identifikasi masalah dan potensi yang dimiliki oleh Desa Lokasi Baru melalui observasi dan wawancara langsung. Selanjutnya disepakati jadwal pelaksanaan program pelatihan yang telah direncanakan oleh tim pengabdian. Jadwal kegiatannya sebagai berikut:

Tabel1. Jadwal Kegiatan Pengabdian

\begin{tabular}{llll}
\hline No & \multicolumn{2}{c}{ Kegiatan } & \multicolumn{1}{c}{$\begin{array}{c}\text { Waktu } \\
\text { Pelaksanaan }\end{array}$} \\
\hline 1 & $\begin{array}{l}\text { Sosialisasi tentang Sistem } \\
\text { Integrasi Sapi Kelapa Sawit } \\
\text { (SISKA) }\end{array}$ & 2021 & September \\
& & \\
\hline 2 & $\begin{array}{l}\text { Penyuluhan pembuatan } \\
\text { pupuk kompos } 21 \text { Oktober 2021 } \\
\text { Vermikompos) }\end{array}$ \\
\hline 3 & $\begin{array}{l}\text { Praktik pembuatan pupuk } \\
\text { kompos 21 Oktober 2021 } \\
\text { vermikompos) }\end{array}$ \\
\hline 4 & Pendampingan dan evaluasi & 21 Oktober - 30 \\
& & Oktober 2021 \\
\hline
\end{tabular}

Alat dan Bahan yang digunakan dalam program ini bebeda dalam setiap kegiatan. Untuk kegiatan sosialisasi dan penyuluhan alat yang digunakan yaitu: 1) spanduk kegiatan; dan 2) flyer.

Sedangkan dalam praktik pembuatan pupuk kompos alat yang digunakan yaitu: 1) cangkul; 2) sekop; 3) parang; 4) arit; 5) gergaji dan 6) palu. Sedangkan bahan yang 
digunakan yaitu: 1) papan GRC; 2) kotoran sapi; dan 3) cacing tanah (Lumbricus sp).

\section{HASIL DAN PEMBAHASAN}

Pelaksanaan kegiatan ini dilakukan dalam empat tahapan. Ketiga tahapan tersebut yaitu: 1) sosialisasi tentang sistem integrasi sapi kelapa sawit (Gambar 1); 2) penyuluhan pembuatan pupuk kompok (metode vermikompos); 3) praktik pembuatan pupuk kompos (metode vermikompos); 4) evaluasi dan pendampingan. Kegiatan sosialisasi dan penyuluhan diberikan secara langsung kepada kelompok sasaran yakni para peternak sapi di Desa Lokasi Baru. Untuk mempermudah kelompok sasaran memahami alur kegiatan, materi sosialisasi dan penyuluhan diberikan pada waktu yang berbeda, yakni pada tanggal 25 September dan 21 Oktober 2021. Kemudian kegiatan dilanjutnya dengan praktik pembuatan pupuk kompos pada tanggal 21 Oktober 2021. Untuk memastikan peserta melakukan semua tahapan dengan tepat maka dilakukan kegiatan pendampingan dan evaluasi terhadap hasil kerja yang telah dilakukan oleh para peserta. Kegiatan ini dilaksanakan pada rentang waktu 21 Oktober - 30 Oktober 2021. Setiap kegiatan di atas dirincikan pada bagian berikut:

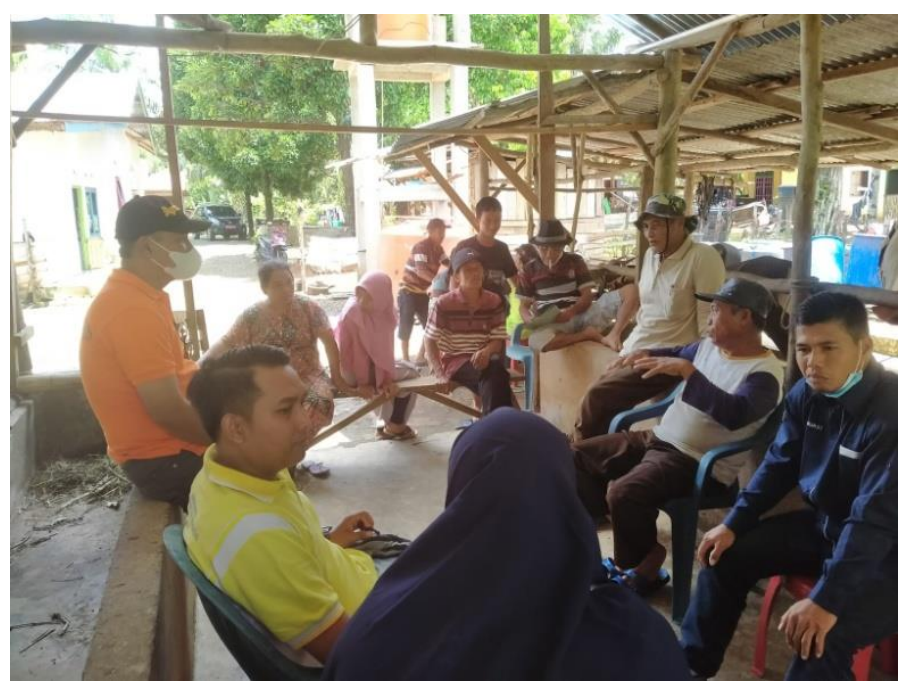

Gambar 1. Kegiatan Sosialisasi bersama mitra

\section{Sosialisasi Sistem Integrasi Sapi Kelapa Sawit}

Dalam kegiatan ini tim pengabdian memberikan handout materi kepada para peserta dan selanjutnya tim pengabdian menyampaikan penjelasan secara rinci terkait materi tersebut. Ringkasan materi yang diberikan sebagai berikut:

"Selama ini petani sawit dihadapkan pada permasalahan rendahnya pendapatan usahatani yang mereka jalani. Hal ini disebabkan karena luas lahan kelapa sawit rakyat relatif kecil dan masih rendahnya produktivitas perkebunan rakyat. Diduga hal ini terjadi karena manajemen usahatani yang dijalani tidak sesuai standar budidaya kelapa sawit, terutama dalam proses pemupukan (Sari, dkk 2015 dan Edwina, dkk 2019).

Sistem integrasi sapi dan kelapa sawit (SISKA) menggabungkan usahatani kelapa sawit dengan peternakan sapi. Hal ini dikarenakan adanya keterkaitan yang erat antara komponen tanaman dan ternak sapi. Limbah perkebunan kelapa sawit berupa pelepah dimanfaatkan sebagai sumber pakan, sedangkan limbah ternak berupa kotoran sapi, baik cair maupun padat dimanfaatkan sebagai pupuk kelapa sawit (Edwina, dkk 2019).

Umumnya petani kelapa sawit menggunakan pupuk anorganik. Dengan menggunakan pupuk anorganik, petani menghabiskan sekitar 25 - $30 \%$ dari total biaya produksi sebagai biaya pemupukan. Penggunaan pola SISKA dalam usaha tani kelapa sawit tentu akan menekan biaya pemupukan (Pahan 2010)."

Setelah materi disampaikan, dilanjutkan dengan sesi diskusi. Pada sesi ini para peserta diberikan kesempatan bertanya dan menyampaikan pandangannya terkait materi yang disampaikan. Antusiasme masyarakat terlihat dari banyaknya pertanyaan dan masukkan yang diberikan pada sesi ini. Sebagai sebuah proses pembelajaran, sumber informasi tidak hanya berasal dari tim pengabdian saja, namun masyarakat juga bisa menjadi informan dalam kegiatan ini. Dengan demikian sesi diskusi menjadi lebih kaya informasi yang dibutuhkan.

\section{Penyuluhan Pembuatan Pupuk Kompos (Metode Vermikompos)}

Kegiatan penyuluhan diberikan kepada kelompok masyarakat yang sama dengan pertemuan sebelumnya. Setiap peserta diberikan handout materi dan tim pengabdian menjelaskan secara rinci materi penyuluhan. Berikut ringkasan materi yang diberikan dalam kegiatan ini:

"Aktivitas peternakan menghasilkan limbah yang dapat menimbulkan dampak negatif bagi lingkungan jika tidak dikelola dengan baik. Dampak yang ditimbulkan antara lain pencemaran udara, air, dan tanah. Selain itu juga dapat menimbulkan gangguan pada estetika dan kenyaman masyarakat sekitar. Lebih jauh lagi limbah ternak juga dapat 
menjadi sumber penyakit serta memicu peningkatan gas metan di atmosfer (Nenobesi, dkk 2017).

Limbah peternakan jika dikelola dengan baik akan menghasilkan pupuk kompos yang bermanfaat bagi kegiatan usahatani. Penggunaan pupuk kompos akan memberikan manfaat berupa peningkatan daya dukung lingkungan, jumlah produksi, efisiensi biaya usahatani dan mengurangi dampak pencemaran lingkungan (Nugraha \& Amini, 2013).

Salah satu alternatif pengolahan limbah yang dihasilkan dari kegiatan peternakan adalah dengan memanfaatkan cacing tanah sebagai pengurai. Metode ini dikenal sebagai vermikompos. Kompos yang dihasilkan dari metode ini berupa campuran kotoran cacing tanah dan sisa media atau pakan dalam budidaya cacing tanah (Mashur, 2001 dan Rahmawati \& Herumurti, 2016).

Selain metodenya yang sederhana, vermikompos juga memiliki beragam keunggulan, yaitu: a) mengandung unsur hara kompleks seperti $\mathrm{N}, \mathrm{P}, \mathrm{K}, \mathrm{Ca}, \mathrm{Mg}, \mathrm{S}, \mathrm{Fe}, \mathrm{Mn}, \mathrm{AI}, \mathrm{Na}, \mathrm{Cu}$, $Z N$, Bo dan Mo; b) mampu memperbaiki daya serap dan daya simpan media tanam terhadap air, sehingga mampu menjaga kelembapan tanah hingga 40-60 persen; c) mampu memperbaiki struktur tanah dan menetralkan $\mathrm{pH}$ tanah; d) menjadi sumber nutrisi bagi mikroba tanah yang membantu meningkatkan kesuburan tanaman; dan e) menyediakan unsur hara terlarut yang dibutuhkan oleh tanaman (Setiyadi, 2020)."

Materi yang diberikan dalam sesi ini merupakan ilmu baru bagi para peserta. Selama ini mereka hanya mengetahui metode pembuatan kompos dengan menggunakan mikroorganisme pengurai. Dengan metode tersebut bahan yang digunakan sangat banyak dan prosesnya pun cukup lama.

Setelah menerima materi vermikompos para peserta mengetahui bahwa ada metode lain yang lebih mudah dilakukan. Oleh karena itu mereka sangat antusias untuk menggali informasi sebanyak-banyaknya dari pemateri. Selain bertanya terkait proses produksi, para peserta juga menanyakan potensi pasar bagi kompos yang akan mereka produksi nanti.

\section{Praktik Pembuatan Pupuk Vermikompos}

Alat yang digunakan yaitu: 1) cangkul; 2) parang; 3) arit; 4) gergaji dan 5) palu.

Sedangkan bahan yang digunakan yaitu: 1) papan GRC; 2) kotoran sapi (bisa menggunakan kotoran ternak seperti ayam, kambing atau domba); 3) Sampah organik (sisa sayuran, buah dan lainnya); 4) Pelepah pisang dan 5) telur dan cacing tanah (Lumbricus sp).

Langkah membuat vermikompos yaitu:

1) Siapkan wadah yang akan menjadi tempat tinggal cacing (worm bin). Membuat kotak berbahan GRC dengan ukuran 1 x 1 x 0,5 meter. Lubangi bagian dasar dan samping agar cacing mendapat sirkulasi udara yang cukup. Letakkan worm bin yang terlindungi dari air hujan dan paparan sinar matahari langsung;

2) Susun pelepah pisang di bagian dasar worm bin sebagai tempat cacing bertelur;

3) Siapkan bahan organik (sampah dan kotoran sapi) yang telah difermentasi sebagai media perkembangan cacing di dalam worm bin.Biasanya proses fermentasi memerlukan waktu selama 2 minggu;

4) Letakkan beberapa cacing di media perkembangan, jika cacing tidak meninggalkan worm bin maka media perkembangan sudah siap. Media yang baik memiliki kelembaban sekitar 50-55\%, suhu berkisar $30-55{ }^{\circ} \mathrm{C}$, pH 5,5-8 dan terdapat aerasi;

5) Jika media perkembangan sudah siap, maka kita bisa menambahkan lebih banyak cacing tanah ke dalamnya. Cacing tanah bisa didapatkan di toko pertanian dalam bentuk cacing hidup atau telur cacing. Menetaskan telur cacing tanah cukup dengan menyimpannya di dalam media perkembangan dan dijaga kelembabannya hingga menetaas ( \pm 3 minggu);

6) Setelah tiga hari, buka worm bin dan lihat apakah kompos sudah mulai terbentuk? Jika bahan organik yang ada di dalam worm bin mulai menghilang, maka tambahkan kembali bahan tersebut. Lakukan hal tersebut berulang-ulang hingga jumlah pupuk yang dihasilkan cukup banyak. Pupuk yang sudah siap digunakan berwarna kehitaman dan tidak berbau.

7) Untuk proses pemanenan dapat dilakukan dengan memisahkan cacing tanah dan pupuk vermikompos. Sisakan pupuk vermikompos secukupnya di worm bin sebagai media perkembangan selanjutnya.

8) Letakkan kembali cacing tanah ke dalam worm bin untuk proses komposting selanjutnya.

\section{Pendampingan dan Evaluasi}

Suharto (2005) menguraikan pendampingan sebagai suatu strategi yang sangat menentukan keberhasilan program pemberdayaan masyarakat. Keterlibatan masyarakat sebagai sumber daya manusia untuk memberdayakan dirinya, merupakan potensi untuk mencapai tujuan masyarakat. 
Setelah materi dan teknis pembuatan vermikompos diajarkan kepada peserta pelatihan, tim pengabdian masih merasa perlu untuk melakukan pendampingan. Hal ini bertujuan agar masyarakat peserta pelatihan mampu mempraktikkan seluruh tahapan pembuatan vermikompos hingga berhasil. Teknis pendampingan dilakukan secara daring melalui whattapp grup. Peserta pelatihan dapat menyampaikan kendala yang mereka hadapi melalui grup yang selanjutnya akan dijawab oleh tim pengabdian.

Tahapan pembuatan vermikompos terbilang mudah dipraktikkan. Meskipun demikian tetap saja ada peserta yang khawatir dengan tahapan yang mereka praktikan secara mandiri. Selama pendampingan berlangsung beberapa kendala yang dihadapi oleh peserta adalah pada tahap persiapan media perkembangan, penetasan telur cacing dan proses komposting.

Pada tahap persiapan media perkembangan peserta kurang sabar dalam menunggu proses fermentasi. Selain itu mereka juga bingung dalam menentukan apakah media perkembangan yang mereka buat sudah sesuai atau belum. Hal ini diakibatkan karena terbatasnya alat pengujian seperti $\mathrm{pH}$ meter ataupun termometer. Sedangkan untuk melihat kriteria secara fisik masih belum mengerti. Akhirnya untuk mensiasati kondisi ini, mereka langsung mencoba dengan meletakkan beberapa cacing ke dalam media tanam dan membiarkannya selama satu malam. Jika cacing keluar dari media tanam, maka mereka harus melanjutkan proses fermentasinya.

Proses penetasan telur cacing juga tidak rumit. Peserta hanya butuh menjaga kelembaban media penetasan telur dan menyimpannya di tempat yang sejuk. Dalam proses ini kendala terbesar adalah tingkat kematian anakan cacing cukup tinggi.

Permasalahan terakhir adalah waktu yang dibutuhkan untuk proses komposting. Biasanya proses komposting memerlukan waktu tiga hari. Namun kondisi ini bisa saja berbeda, tergantung dengan jumlah cacing yang ada di dalam worm bin. Semakin banyak cacing yang dimiliki, maka proses komposting akan semakin singkat. Untuk itu peserta harus lebih bersabar dalam memulai usaha ini.

\section{KESIMPULAN}

Setelah seluruh rangkaian kegiatan dilaksanakan Masyarakat Desa Lokasi Baru lebih memahami bahwa kotoran ternak yang selama ini mereka anggap sebagai limbah ternyata memiliki nilai ekonomi jika dapat diolah dengan baik. Saat ini sebagian peserta telah mempraktikkan secara mandiri proses pengkomposan dengan metode vermikompos ini.

\section{UCAPAN TERIMAKASIH}

Terimakasih kepada semua pihak yang sudah membantu dalam penyelesaian kegiatan pengabdian ini. Dekan Fakultas Pertanian Universitas Bengkulu beserta jajarannya yang telah mendukung terlaksananya kegiatan ini. Ketua Jurusan Sosial Ekonomi Pertanian dan tim panitia pelaksana yang telah memfasilitasi terlaksananya kegiatan pengabdian ini. Kepala desa dan seluruh masyarakat Desa Lokasi Baru yang telah bersedia menerima tim pengabdian Unib dan berpartisipasi aktif dalam setiap kegiatan yang telah dilaksanakan.

\section{DAFTAR PUSTAKA}

Anonim. 2017. RPJM Desa Lokasi Baru Kecamatan Air Periukan Kab. Seluma 2017-2023

Direktorat Jenderal Peternakan. 2019. Program Swasembada Daging Sapi. Jakarta: Direktorat Jenderal Peternakan

Edwina, S., J. Y., Yusmini, \& E. M. 2019.Kajian Perbandingan Produktivitas dan Pendapatan Perkebunan Pola Sistem Integrasi Sapi dan Kelapa Sawit (Siska) dengan Perkebunan Tanpa Pola Siska di Kabupaten Siak.Mimbar Agribisnis 5 (1) , 90 - 103

Kementerian Pertanian RI. 2020. BPS, Pertanian Tumbuh Positif 2,15 Persen YonY di Kuartal ke III. Retrieved Juni 17, 2021, from Kementerian Pertanian Republik Indonesia: https://www.pertanian.go.id/home/?show=news\&act= view\&id=4561

Mashur. 2001. Vermikompos (Kompos Cacing Tanah) Pupuk Organik Berkualitas dan Ramah Lingkungan. Instalasi Penelitian dan Pengkajian Teknologi Pertanian (IPPTP) Mataram Badan Penelitian dan Pengembangan Pertanian

Mulyani, A., D. Kuncoro., D. Nursyamsi., \&F. Agus. 2016. Analisis Konversi Lahan Sawah: Penggunaan Data Spasial Resolusi Tinggi Memperlihatkan Laju Konversi yang Mengkhawatirkan. Jurnal Tanah dan Iklim 40 (2) , $121-133$.

Pahan, I. 2010. Panduan Lengkap Kelapa Sawit. Jakarta: Penebar Swadaya.

Rahmawati, E., \& Herumurti, W. 2016. Vermikompos Sampah Kebun dengan Menggunakan Cacing Tanah Eudrilus eugeneae dan Eisenia fetida. Jurnal Teknik ITS, 5 (1): 33-37

Sari, V. I., Sudrajat, \& Sugiyanta.2015. Peran Pupuk Organik dalam Meningkatkan Efektivitas Pupuk NPK pada Bibit Kelapa Sawit di Pembibitan Utama.Jurnal Agronomi Indonesia 43 (2) , 153-160. 
Setiyadi, Y. 2020. Vermikompos: Pupuk dengan Kandungan Unsur Hara Kompleks. Ensiklo.com. Diakses pada 28 November 2021 https://ensiklo.com/2020/09/03/vermikompospupuk-dengan-kandungan-unsur-hara-kompleks/\#

Suharto, E. 2005. Membangun Masyarakat Memberdayakan Rakyat. Bandung: Refika Aditama 